Article

\title{
Reactive Sintering Mechanism and Phase Formation in Ni-Ti-Al Powder Mixture During Heating
}

\author{
Pavel Salvetr *, Andrea Školáková, Cyprien Hudrisier, Pavel Novák and Dalibor Vojtěch \\ Department of Metals and Corrosion Engineering, University of Chemistry and Technology, Prague, \\ Technická 5, 16628 Prague, Czech Republic; andrea.skolakova@vscht.cz (A.Š.); cyprien.hud@orange.fr (C.H.); \\ panovak@vscht.cz (P.N.); vojtechd@vscht.cz (D.V.) \\ * Correspondence: salvetrp@vscht.cz; Tel.: +420-220-44-4441
}

Received: 28 March 2018; Accepted: 27 April 2018; Published: 27 April 2018

\begin{abstract}
This work aims to describe the formation of intermetallics in the Ni-Ti-Al system in dependence on the heating rate, which has been determined previously as the crucial factor of thermal explosion self-propagating synthesis (TE-SHS). The tested alloys contained $1-7 \mathrm{wt} \%$ aluminum. Thermal analysis has been realized by the optical pyrometer under the conditions of high heating rates up to $110^{\circ} \mathrm{C} \cdot \mathrm{min}^{-1}$. TE-SHS process in Ni-Ti-Al system is initiated by exothermic reaction of nickel aluminides $\mathrm{Ni}_{2} \mathrm{Al}_{3}$ and $\mathrm{NiAl}_{3}$ at the temperature of $535-610{ }^{\circ} \mathrm{C}$. The next reactions occur in dependence on the heating rate. Samples containing 1-3 wt \% of aluminum exhibit the similar initiation temperature as Ni-Ti binary mixture. The samples containing $5 \mathrm{wt} \%$ and more of aluminum were fully reacted after sintering at $800{ }^{\circ} \mathrm{C}$ with the heating rate of $300^{\circ} \mathrm{C} \cdot \mathrm{min}^{-1}$ and the initiation temperature of the TE-SHS was observed close to $\mathrm{Al}-\mathrm{Al}_{3} \mathrm{Ni}$ eutectic temperature (between $630-640{ }^{\circ} \mathrm{C}$ ).
\end{abstract}

Keywords: intermetallics; reactive sintering; self-propagating high-temperature synthesis (SHS); $\mathrm{Ni}$-Ti-Al alloy; differential thermal analysis

\section{Introduction}

Some binary and ternary intermetallic compounds based on nickel, aluminum, titanium, and iron excel in properties like good mechanical properties, shape memory, thermal stability, and also low density. For example Ti-Al alloys with low density and at the same time high mechanical properties are appropriate for aerospace industry. The addition of silicon improves the oxidation resistance at high temperatures [1]. The approximately equimolar Ni-Ti alloy is a well-known shape memory material. The shape memory effects are caused by non-diffusion phase transformation between austenite (high-temperature cubic structure) and martensite (low-temperature monoclinic structure) in the NiTi intermetallic phase. Intermetallics are usually produced by conventional melting and casting methods such as vacuum induction melting (VIM) and vacuum arc re-melting (VAR) [2]. These production methods are expensive and problematic due to high reactivity of melt and poor casting properties. The carbon crucibles react with the melt. Therefore the special crucibles coated by zirconia or yttria must be used for Ni-Ti alloys and the production price grows [3]. Powder metallurgy offers perspective methods of production of Ni-Ti alloys and other intermetallic compounds [2,4-8]. The elemental powders are mixed and pressed and consequently the pressed powder mixture compact is heated to the ignition temperature (which is lower than the melting point). The exothermic combustion reaction is initiated and leads to the formation of intermetallic phases. If the whole compressed compact is heated at the same time, the process is called 'thermal explosion mode of self-propagating high-temperature synthesis' (TE-SHS). If the heat source is focused only on one side of the compressed powder mixture compact and the reaction goes through the compact gradually, the mode of SHS reaction is called 'plane wave propagation mode' [9]. In the binary Ni-Ti system, the eutectic temperature $942{ }^{\circ} \mathrm{C}$ has 
been stated to be the initial temperature of the SHS reaction in some publications [10]. The initial temperature of approximately $890^{\circ} \mathrm{C}$ was found out and the start of reaction is connected with $\alpha \rightarrow \beta$ titanium transformation at the temperature of $882^{\circ} \mathrm{C}$ [7]. The influence of heating rate, temperature of reactive sintering, particle sizes of nickel and titanium powders on microstructure, phase composition, and porosity were investigated in many publications [4,10-13].

The addition of aluminum into the near equiatomic Ni-Ti powder mixture was researched and the decrease of porosity and improvement of corrosion resistance and hardness were reported [14]. The two exothermic peaks were measured during heating of $\mathrm{Ni}-\mathrm{Ti}-\mathrm{Al}$ pressed compact containing $10-40$ at $\%$ of aluminum. The first peak was observed at the temperature range of $595-625{ }^{\circ} \mathrm{C}$, being related to the reaction between nickel and aluminum at eutectic point at the temperature of $640{ }^{\circ} \mathrm{C}$. The second exothermic peak accompanies the reaction between nickel and titanium in the temperature range $938-946^{\circ} \mathrm{C}$ at approximately eutectic point. Increasing amount of aluminum leads to higher exothermicity of the first peak and to lower exothermicity of the second peak [15].

In the present study, the addition of a low amount of aluminum (1-7 wt \%) into the near equiatomic $\mathrm{Ni}$-Ti powder mixture is studied. The mechanism of the reactions was studied in dependence of the heating rate.

\section{Results and Discussion}

The DTA heating curves of the equimolar NiTi46 and NiTiAl powder mixtures with various content of aluminum (1-7 wt \%) are presented in Figure 1. There is only one strong exothermic peak with the onset temperature at $949{ }^{\circ} \mathrm{C}$ in the binary NiTi46 alloy. This peak corresponds with the temperature of the eutectic reaction $\left(\beta-\mathrm{Ti}+\mathrm{Ti}_{2} \mathrm{Ni} \rightarrow \mathrm{L}\right)$ at $942{ }^{\circ} \mathrm{C}$, which has been reported recently as the ignition point of the TE-SHS reaction [10]. The new exothermic double-peak appeared below the melting point of aluminum. The first part of the peak $\left(535-610^{\circ} \mathrm{C}\right)$ represents formation of the nickel aluminides- $\mathrm{Ni}_{2} \mathrm{Al}_{3}$, the $\mathrm{Ni}_{3} \mathrm{Ti}$ and $\mathrm{Ti}_{2} \mathrm{Ni}$ phases were formed due to solid state reaction, moreover unreacted nickel and titanium particles were identified by XRD patterns NiTiAl5 powder mixtures heated to $610^{\circ} \mathrm{C}$ for $20 \mathrm{~min}$ (see in Figure 2) and these XRD results are in agreement with previous publications [15]. The strongly exothermic part of this peak (onset at approximately $632^{\circ} \mathrm{C}$ ) represents the TE-SHS reaction in the NiTiAl5 and NiTiAl7 powder mixture. The amount of 1 and $3 \mathrm{wt} \%$ of aluminum in powder mixture is not ample for initiation of reaction in the whole powder mixture. There is only a very weak exothermic peak in the NiTiAl1 sample detected at $633^{\circ} \mathrm{C}$.

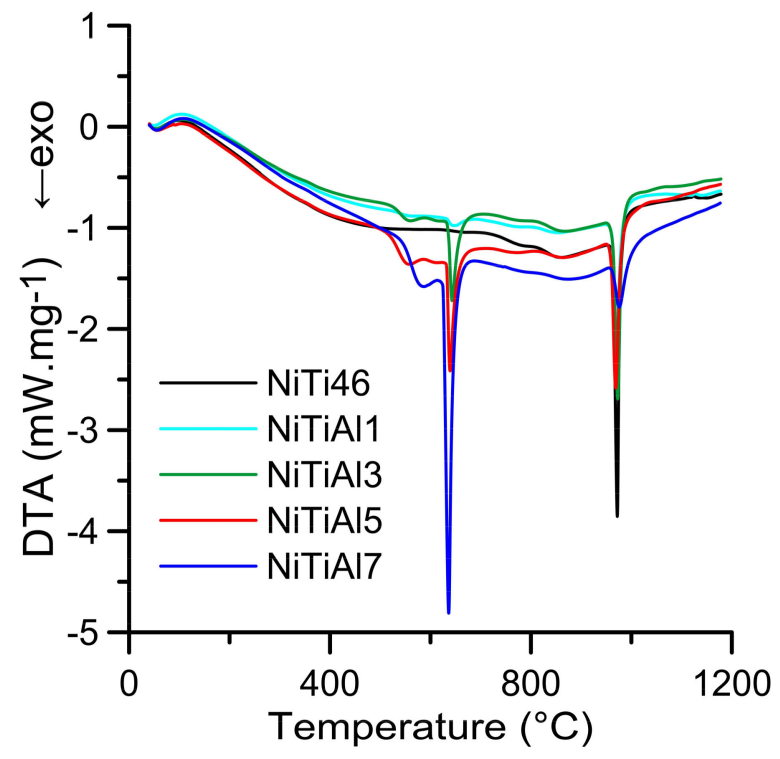

Figure 1. DTA heating curves of NiTi46 and NiTiAl1-7 to $1200{ }^{\circ} \mathrm{C}$. 


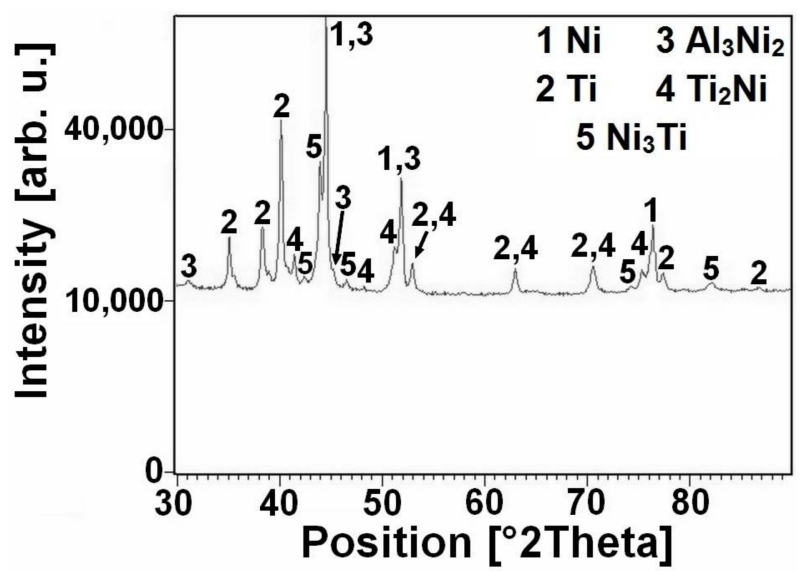

Figure 2. XRD pattern of NiTiAl5 sintered at $610{ }^{\circ} \mathrm{C}$ with duration of $20 \mathrm{~min}$ and quickly cooled in water.

The heat generated by the solid state reaction can lead to local formation of eutectic melt and to a rapid a strong support of the occurring reaction which represented the second part of the double-peak starting at the temperature interval $615-635{ }^{\circ} \mathrm{C}$ (the initiation temperature decreases with increasing aluminum content). The relative heat release $(\Delta \mathrm{H})$ associated with the exothermic reactions occurring in the range of $535-650{ }^{\circ} \mathrm{C}$ increases with aluminum content, see in Figure 3. The significant exothermic peak appeared in samples with the addition of aluminum in the amount of 3-7 wt \%. However, the heat released by these reactions is not sufficient for reaction in the whole NiTiAl3 powder mixture.

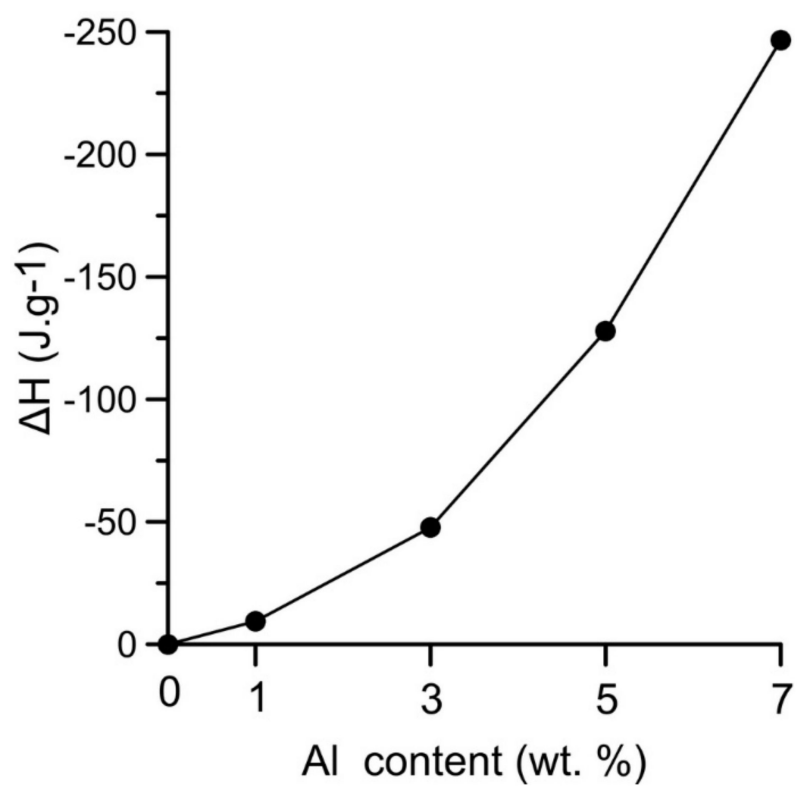

Figure 3. Relative heat associated with reaction at $535-650{ }^{\circ} \mathrm{C}$ depending on aluminum content in powder mixture.

The similar phase evolution was observed in publication [15], the little shift of the measured peak's temperature is caused by the use of a lower DSC (differential scanning calorimetry) heating rate $\left(20^{\circ} \mathrm{C} \cdot \mathrm{min}^{-1}\right)$. The exothermic reaction close to temperatures of $942-955^{\circ} \mathrm{C}$ is similar to the eutectic reaction in the binary Ni-Ti system. The influence of heating rate was studied in publication [4] and it was found that the higher heating rate leads to lower content of the $\mathrm{Ti}_{2} \mathrm{Ni}$ phase in the sintered product. The combination of induction furnace and optical pyrometer was used as the alternative way to DTA (differential thermal analysis), enabling observation of thermal effects during the heating with the 
higher heating rates of approximately $100{ }^{\circ} \mathrm{C} \cdot \mathrm{min}^{-1}$. The initiation temperature of $863^{\circ} \mathrm{C}$ was measured in the NiTi46 alloy and the addition of 1 and $3 \mathrm{wt} \%$ of aluminum slightly increased this temperature $\left(\mathrm{NiTiAl1}-869^{\circ} \mathrm{C}, \mathrm{NiTiAl3}-885^{\circ} \mathrm{C}\right.$ ). The reason for this effect consists in partial reaction around the elemental particles at the temperature of $632{ }^{\circ} \mathrm{C}$. This reaction is possible to see in a heating curve recorded by optical pyrometer in the sample NiTiAl3, where is the minor peak at $632{ }^{\circ} \mathrm{C}$ (Figure 4 ).

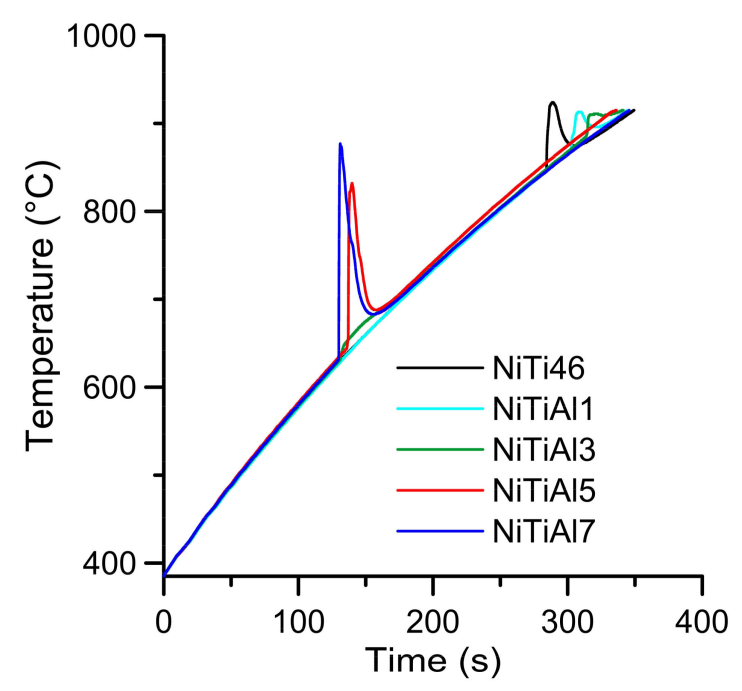

Figure 4. Heating curves of NiTi46 and NiTiAl1-7, recorded by optical pyrometer.

The reacted layer suppresses the TE-SHS at higher temperatures. In the NiTiAl3 sample, there the aluminides and $\mathrm{Ti}_{2} \mathrm{Ni}$ layer are thicker and, therefore, the TE-SHS starts at higher temperatures than in the NiTiAl1 sample. A similar effect prevents the possibility to sinter elemental Ni-Ti powder mixture in spark plasma sintering (SPS) [16]. There is the initiation temperature at $632{ }^{\circ} \mathrm{C}$ from 5 to 7 wt $\%$ of aluminum addition into powder mixture. The heating curves of the DTA and optical pyrometer are in good agreement with NiTiAl samples, and the initiation temperature of TE-SHS reaction was measured below the $882{ }^{\circ} \mathrm{C}$ (the $\alpha \rightarrow \beta \mathrm{Ti}$ ) in the NiTi46 powder mixture. The results of XRD analysis for NiTi46 and NiTiAl1-7 samples sintered at 800 and $1100{ }^{\circ} \mathrm{C}$ with the heating rate of approximately $300{ }^{\circ} \mathrm{C} \cdot \mathrm{min}^{-1}$ are stated in Figures 5-9 and they correspond with measuring in induction furnace and pyrometer because TE-SHS was completed fully at $800{ }^{\circ} \mathrm{C}$ in the samples with 5 and 7 wt $\%$ of aluminum.

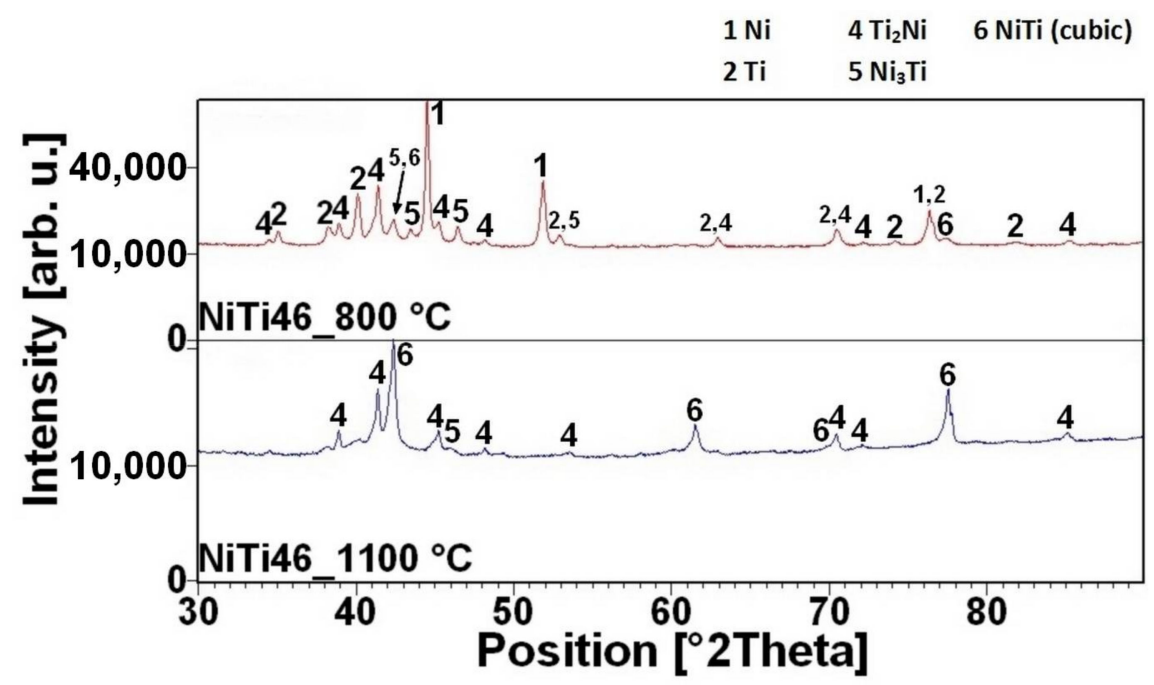

Figure 5. XRD patterns of the NiTi46 sample sintered at 800 and $1100{ }^{\circ} \mathrm{C}$. 


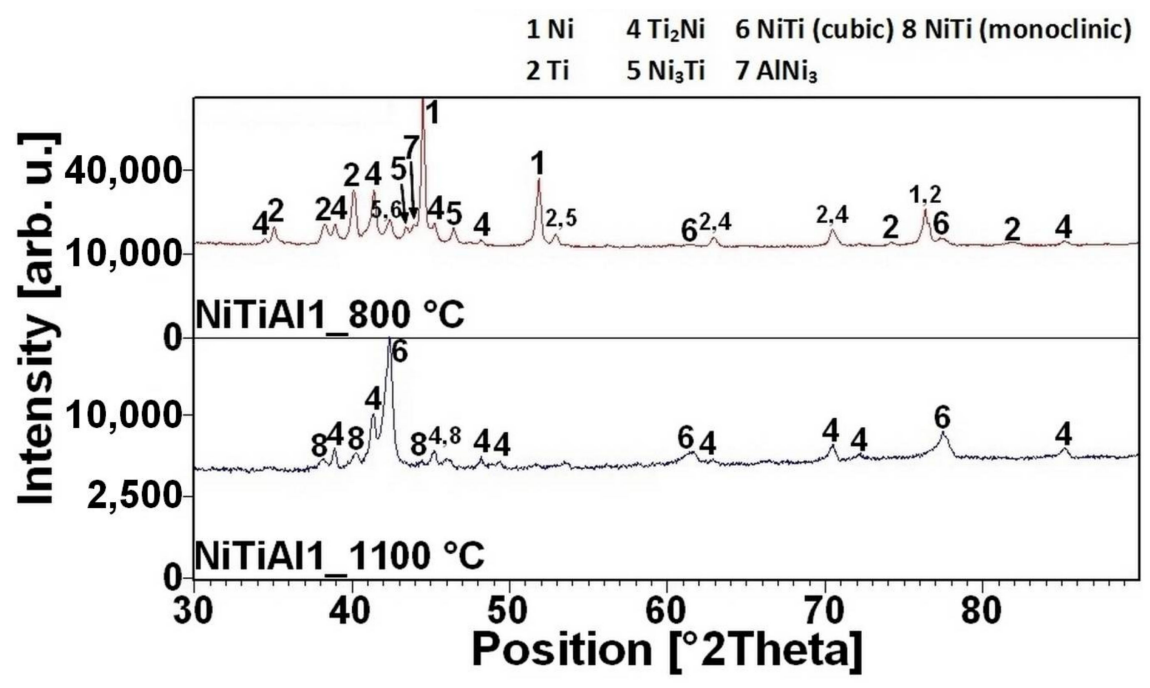

Figure 6. XRD patterns of the NiTiAl1 sample sintered at 800 and $1100{ }^{\circ} \mathrm{C}$.

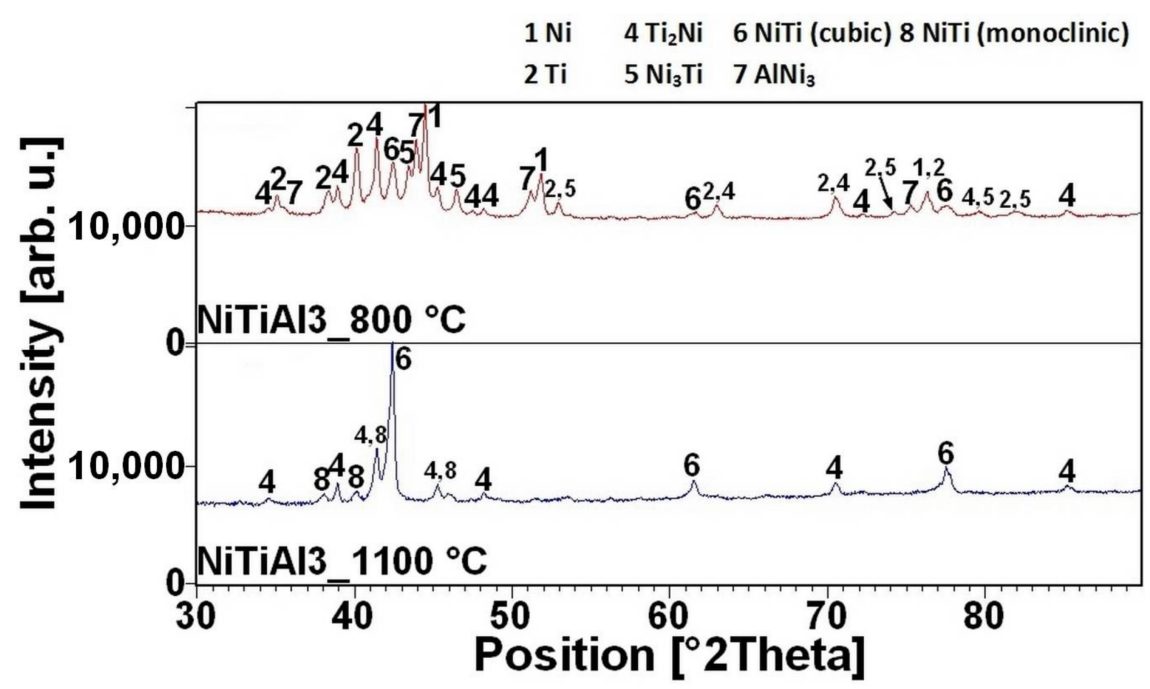

Figure 7. XRD patterns of the NiTiAl3 sample sintered at 800 and $1100{ }^{\circ} \mathrm{C}$.

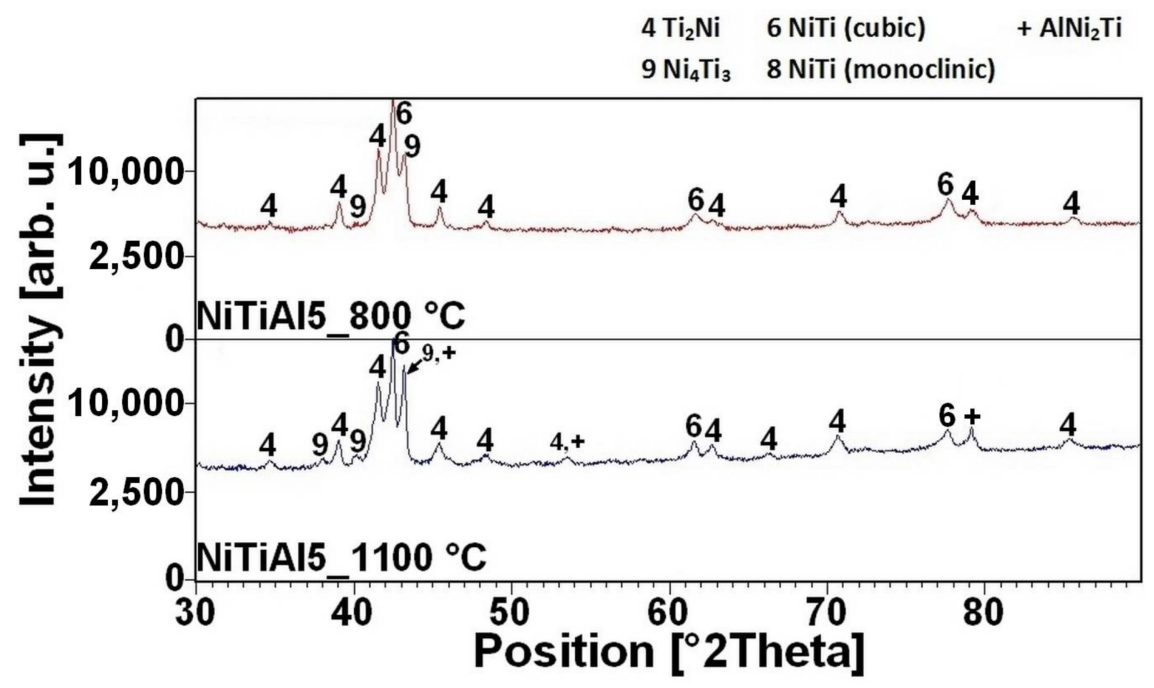

Figure 8. XRD patterns of the NiTiAl5 sample sintered at 800 and $1100{ }^{\circ} \mathrm{C}$. 


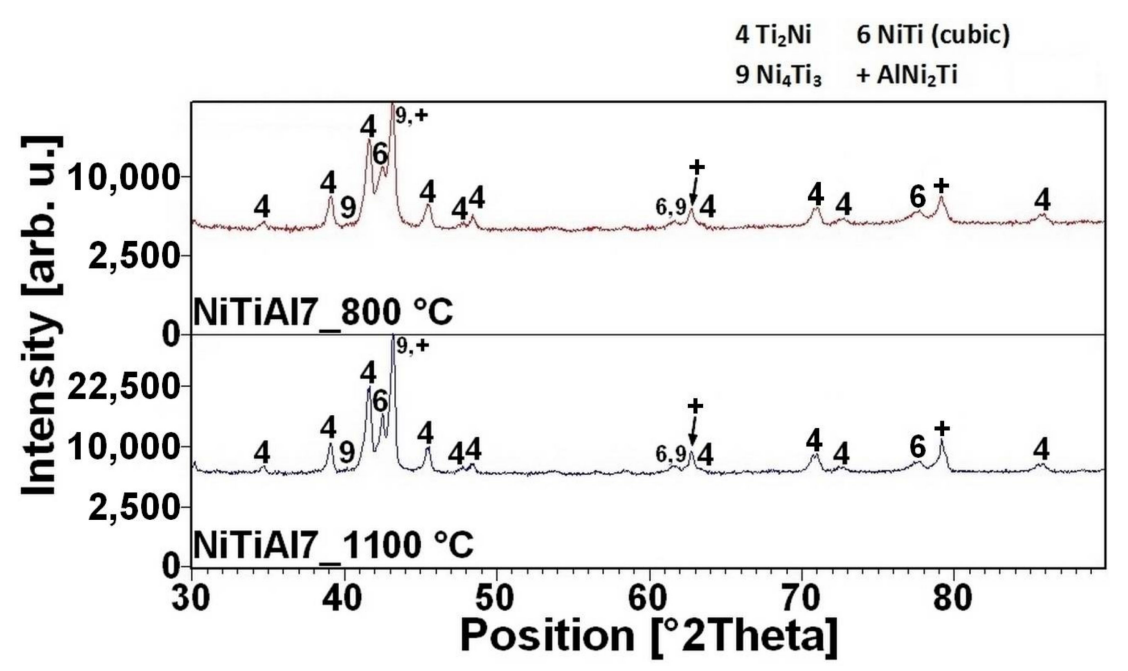

Figure 9. XRD patterns of the NiTiAl7 sample sintered at 800 and $1100{ }^{\circ} \mathrm{C}$.

The high amount of unreacted nickel and titanium particles layered with the $\mathrm{Ti}_{2} \mathrm{Ni}$ phase and nickel aluminides remains in the samples with contents of aluminum up to $3 \mathrm{wt} \%$ at the sintering temperature of $800{ }^{\circ} \mathrm{C}$. The aluminum content is low. Therefore, only areas with higher content of aluminum (labelled $\mathrm{C}$ in Figure 10) were observed. The microstructures of binary NiTi46, ternary NiTiAl1, NiTiAl3, NiTiAl5, and NiTiAl7 samples sintered at 800 and $1100^{\circ} \mathrm{C}$ are shown in Figure 10. It is possible to observe that high sintering temperatures support formation of individual phases and hence, at higher sintering temperatures, there are larger areas of phases due to easier diffusional reaction.

The NiTi phase matrix without the unreacted titanium and nickel particles was formed at the sintering temperature of $800{ }^{\circ} \mathrm{C}$, when the reaction mixture contained over $5 \mathrm{wt} \%$ of aluminum. $\mathrm{The} \mathrm{Ni}_{4} \mathrm{Ti}_{3}$ phase was formed in the NiTiAl5 samples sintered at both temperatures according to XRD analysis. This phase is a precursor for the formation of some aluminides phase, probably for the $\mathrm{AlNi}_{2} \mathrm{Ti}$ phase. The microstructures of the samples with the highest addition of aluminum NiTiAl7 are similar, only the diffusion at the higher temperature of sintering enables to create the coarser grain microstructure. The area fraction of the $\mathrm{Ti}_{2} \mathrm{Ni}$ phase increases with the increasing aluminum content in the fully-reacted samples. The samples sintered at the lower temperature contain more $\mathrm{Ti}_{2} \mathrm{Ni}$ phase in comparison with the NiTiAl5 and NiTiAl7 samples, see in Table 1. The chemical composition of the individual phases determined by EDS is summarized in Table 1 . The content of $5 \mathrm{wt} \%$ of aluminum is the trigger for formation of new phases with high amounts of aluminum in microstructures.

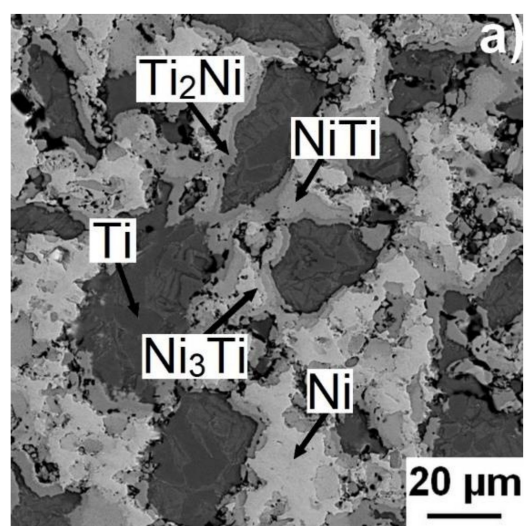

(a)

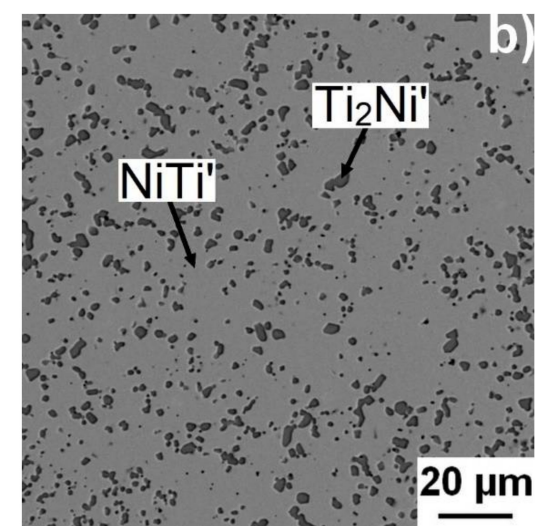

(b)

Figure 10. Cont. 


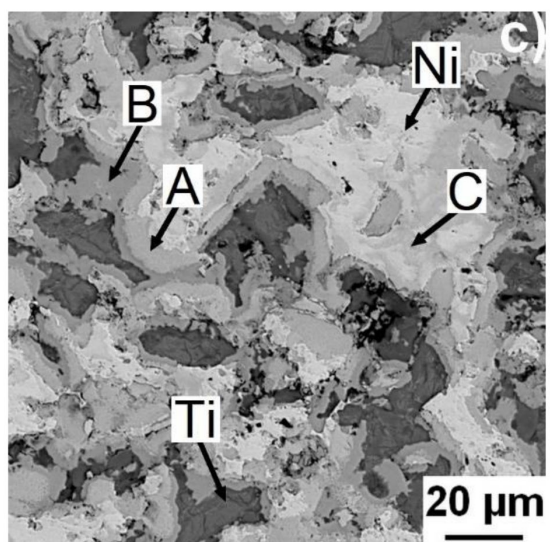

(c)

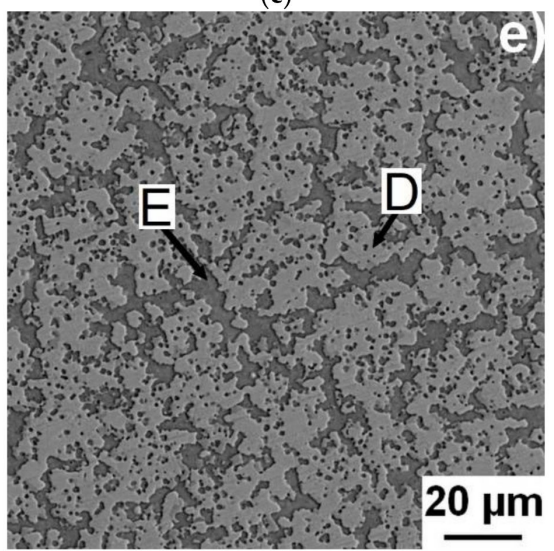

(e)

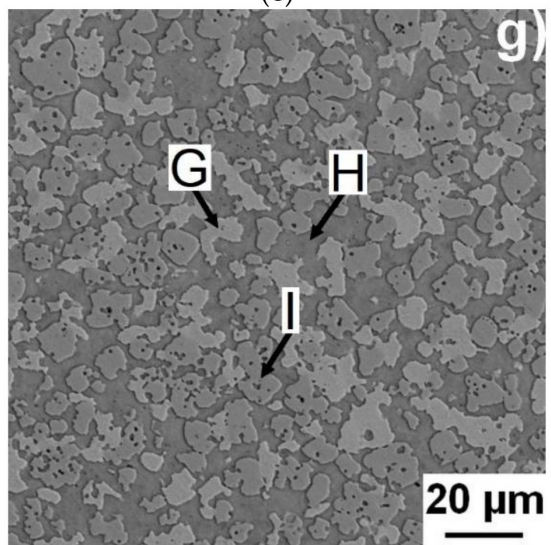

(g)

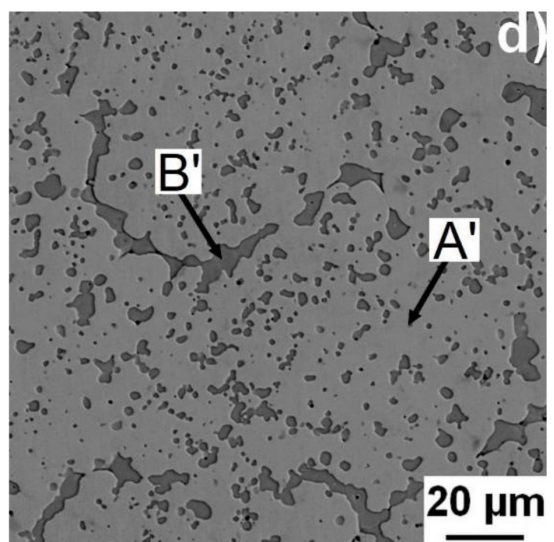

(d)

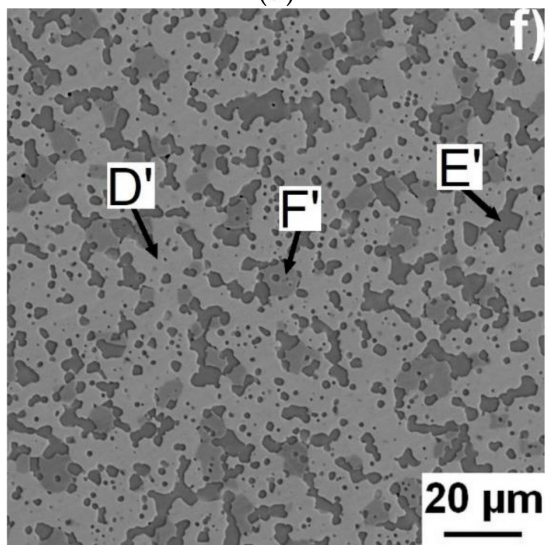

(f)

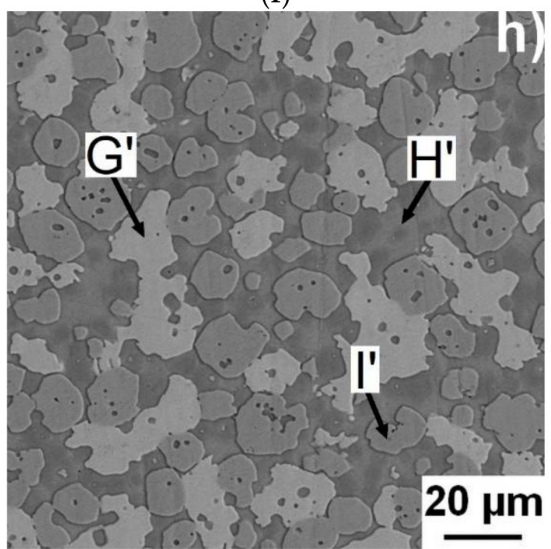

(h)

Figure 10. Microstructures of NiTi46 sintered at (a) $800{ }^{\circ} \mathrm{C}$ and (b) $1100{ }^{\circ} \mathrm{C}$; NiTiAl3 at (c) $800{ }^{\circ} \mathrm{C}$ and (d) $1100{ }^{\circ} \mathrm{C}$; NiTiAl5 at (e) $800{ }^{\circ} \mathrm{C}$ and (f) $1100{ }^{\circ} \mathrm{C}$; and NiTiAl7 at (g) $800{ }^{\circ} \mathrm{C}$ and (h) $1100{ }^{\circ} \mathrm{C}$. The labels of $\mathrm{A}-\mathrm{I}$ and $\mathrm{A}^{\prime}-\mathrm{I}^{\prime}$ term places of chemical analysis stated in Table 1. 
Table 1. Phase compositions and chemical compositions of individual phases of samples sintered at 800 and $1100^{\circ} \mathrm{C}$.

\begin{tabular}{|c|c|c|c|c|c|}
\hline Sample & Area & Ni (wt \%) & $\operatorname{Ti}(w t \%)$ & $\mathrm{Al}(w \mathrm{t} \%)$ & $\begin{array}{l}\text { Area fraction of } \\
\mathrm{Ti}_{2} \mathrm{Ni} \text { phase }(\%)\end{array}$ \\
\hline \multirow{3}{*}{$\mathrm{NiTi} 46800^{\circ} \mathrm{C}$} & $\mathrm{NiTi}$ & $51.3 \pm 0.25$ & $48.7 \pm 0.25$ & 0.0 & \multirow{3}{*}{-} \\
\hline & $\mathrm{Ti}_{2} \mathrm{Ni}$ & $36.2 \pm 0.32$ & $63.8 \pm 0.32$ & 0.0 & \\
\hline & $\mathrm{Ni}_{3} \mathrm{Ti}$ & $75.9 \pm 0.54$ & $24.1 \pm 0.54$ & 0.0 & \\
\hline \multirow{2}{*}{ NiTi46 $1100^{\circ} \mathrm{C}$} & $\mathrm{NiTi}^{\prime}$ & $54.2 \pm 0.08$ & $45.8 \pm 0.08$ & 0.0 & \multirow{2}{*}{$11.7 \pm 0.74$} \\
\hline & $\mathrm{Ti}_{2} \mathrm{Ni}^{\prime}$ & $37.4 \pm 0.08$ & $62.6 \pm 0.08$ & 0.0 & \\
\hline \multirow{2}{*}{ NiTiAl1 $800{ }^{\circ} \mathrm{C}$} & $\mathrm{NiTi}$ & $52.0 \pm 0.50$ & $48.0 \pm 0.50$ & 0.0 & \multirow{2}{*}{-} \\
\hline & $\mathrm{Ti}_{2} \mathrm{Ni}$ & $36.1 \pm 0.43$ & $63.9 \pm 0.43$ & 0.0 & \\
\hline \multirow{2}{*}{ NiTiAl1 $1100{ }^{\circ} \mathrm{C}$} & NiTi & $54.1 \pm 0.18$ & $45.0 \pm 0.21$ & $0.9 \pm 0.05$ & \multirow{2}{*}{$14.7 \pm 0.91$} \\
\hline & $\mathrm{Ti}_{2} \mathrm{Ni}$ & $39.4 \pm 0.32$ & $60.2 \pm 0.26$ & $0.4 \pm 0.08$ & \\
\hline \multirow{3}{*}{ NiTiAl3 $800^{\circ} \mathrm{C}$} & A & $53.7 \pm 1.15$ & $46.2 \pm 1.15$ & 0.0 & \multirow{3}{*}{-} \\
\hline & $\mathrm{B}\left(\mathrm{Ti}_{2} \mathrm{Ni}\right)$ & $37.2 \pm 0.35$ & $62.8 \pm 0.35$ & 0.0 & \\
\hline & C & $82.0 \pm 3.55$ & $7.2 \pm 5.95$ & $10.8 \pm 2.54$ & \\
\hline \multirow{2}{*}{$\mathrm{NiTiAl3} 1100^{\circ} \mathrm{C}$} & $A^{\prime}$ & $53.5 \pm 0.10$ & $43.4 \pm 0.10$ & $3.1 \pm 0.04$ & \multirow{2}{*}{$17.1 \pm 1.73$} \\
\hline & $\mathrm{B}^{\prime}\left(\mathrm{Ti}_{2} \mathrm{Ni}\right)$ & $37.5 \pm 0.27$ & $59.7 \pm 0.26$ & $2.8 \pm 0.05$ & \\
\hline \multirow{2}{*}{$\mathrm{NiTiAl5} 800^{\circ} \mathrm{C}$} & $\mathrm{D}$ & $54.4 \pm 0.82$ & $41.2 \pm 0.94$ & $4.4 \pm 0.19$ & \multirow{2}{*}{$36.2 \pm 1.08$} \\
\hline & $\mathrm{E}$ & $38.1 \pm 0.37$ & $57.7 \pm 0.50$ & $4.2 \pm 0.21$ & \\
\hline \multirow{3}{*}{ NiTiAl5 $1100{ }^{\circ} \mathrm{C}$} & $\mathrm{D}^{\prime}$ & $53.2 \pm 0.14$ & $42.5 \pm 0.15$ & $4.3 \pm 0.11$ & \multirow{3}{*}{$24.4 \pm 1.41$} \\
\hline & $\mathrm{E}^{\prime}\left(\mathrm{Ti}_{2} \mathrm{Ni}\right)$ & $37.7 \pm 0.50$ & $58.8 \pm 0.72$ & $3.5 \pm 0.24$ & \\
\hline & $F^{\prime}$ & $58.7 \pm 0.08$ & $30.1 \pm 0.14$ & $11.2 \pm 0.13$ & \\
\hline \multirow{3}{*}{ NiTiAl7 $800{ }^{\circ} \mathrm{C}$} & G & $54.7 \pm 0.34$ & $40.3 \pm 0.37$ & $5.0 \pm 0.12$ & \multirow{3}{*}{$42.8 \pm 2.07$} \\
\hline & $\mathrm{H}\left(\mathrm{Ti}_{2} \mathrm{Ni}\right)$ & $38.6 \pm 0.39$ & $55.9 \pm 0.46$ & $5.5 \pm 0.19$ & \\
\hline & I & $58.3 \pm 0.20$ & $30.4 \pm 0.21$ & $11.3 \pm 0.15$ & \\
\hline \multirow{3}{*}{$\mathrm{NiTiAl7} 1100^{\circ} \mathrm{C}$} & $\mathrm{G}^{\prime}$ & $53.8 \pm 0.17$ & $42.0 \pm 0.14$ & $4.2 \pm 0.05$ & \multirow{3}{*}{$36.0 \pm 2.23$} \\
\hline & $\mathrm{H}^{\prime}\left(\mathrm{Ti}_{2} \mathrm{Ni}\right)$ & $37.8 \pm 0.29$ & $57.8 \pm 0.83$ & $4.4 \pm 0.56$ & \\
\hline & $\mathrm{I}^{\prime}$ & $58.9 \pm 0.14$ & $30.0 \pm 0.12$ & $11.1 \pm 0.05$ & \\
\hline
\end{tabular}

The influence of aluminum on hardness and sinterability is presented in Figure 11. The lower hardness was measured in partially sintered samples of NiTi46, NiTiAl1, and NiTiAl3 at $800{ }^{\circ} \mathrm{C}$ in comparison with the sintering temperature of $1100^{\circ} \mathrm{C}$. The increasing amount of aluminum increases the hardness of the samples sintered at $800^{\circ} \mathrm{C}$; because aluminum can react larger volumes of samples, more liquid phase was formed, and the powders' boundaries are better interconnected. This is confirmed by hardness measurement when the hardness of partially reacted powder mixture at the temperature of $80{ }^{\circ} \mathrm{C}$ increases with growing aluminum amount in the samples. The difference of hardness by using two sintering temperatures is also observed by higher aluminum content ( 5 and $7 \mathrm{wt} \%)$, but the difference in hardness decreases with the increasing aluminum addition into the samples.

The reaction mechanism was confirmed by the comparison with study [15] in which higher amount of aluminum was added into the $\mathrm{Ni}$-Ti-Al powder mixture. The initial reactions are connected with the formation of nickel aluminides $\left(\mathrm{Ni}_{2} \mathrm{Al}_{3}\right.$ and $\left.\mathrm{NiAl}_{3}\right)$ and the melt can be formed due to released heat from these reactions, even though the initiation temperature is below the eutectic temperature. The released heat is possible to measure since it significantly increases at $1 \mathrm{wt} \%$ of aluminum in powder mixture. The eutectic melt leads to acceleration of the occurring diffusional reaction $\left(\mathrm{Ti}_{2} \mathrm{Ni}\right.$ phase and nickel and titanium aluminides) up to the temperature of TE-SHS between nickel and titanium at $942{ }^{\circ} \mathrm{C}$. These reactions are studied under the conditions of lower heating rate, for example $20{ }^{\circ} \mathrm{C} \cdot \mathrm{min}^{-1}$ in [10]. The high heating rates $\left(100^{\circ} \mathrm{C} \cdot \mathrm{min}^{-1}\right.$ in induction furnace and higher heating rate of $300{ }^{\circ} \mathrm{C} \cdot \mathrm{min}^{-1}$ achieved by inserting of samples into preheated electric resistance furnace) lead to TE-SHS at the temperature under the eutectic point in the Ni-Ti binary system and bellow the temperature $882-890^{\circ} \mathrm{C}$ stated in [7]. 


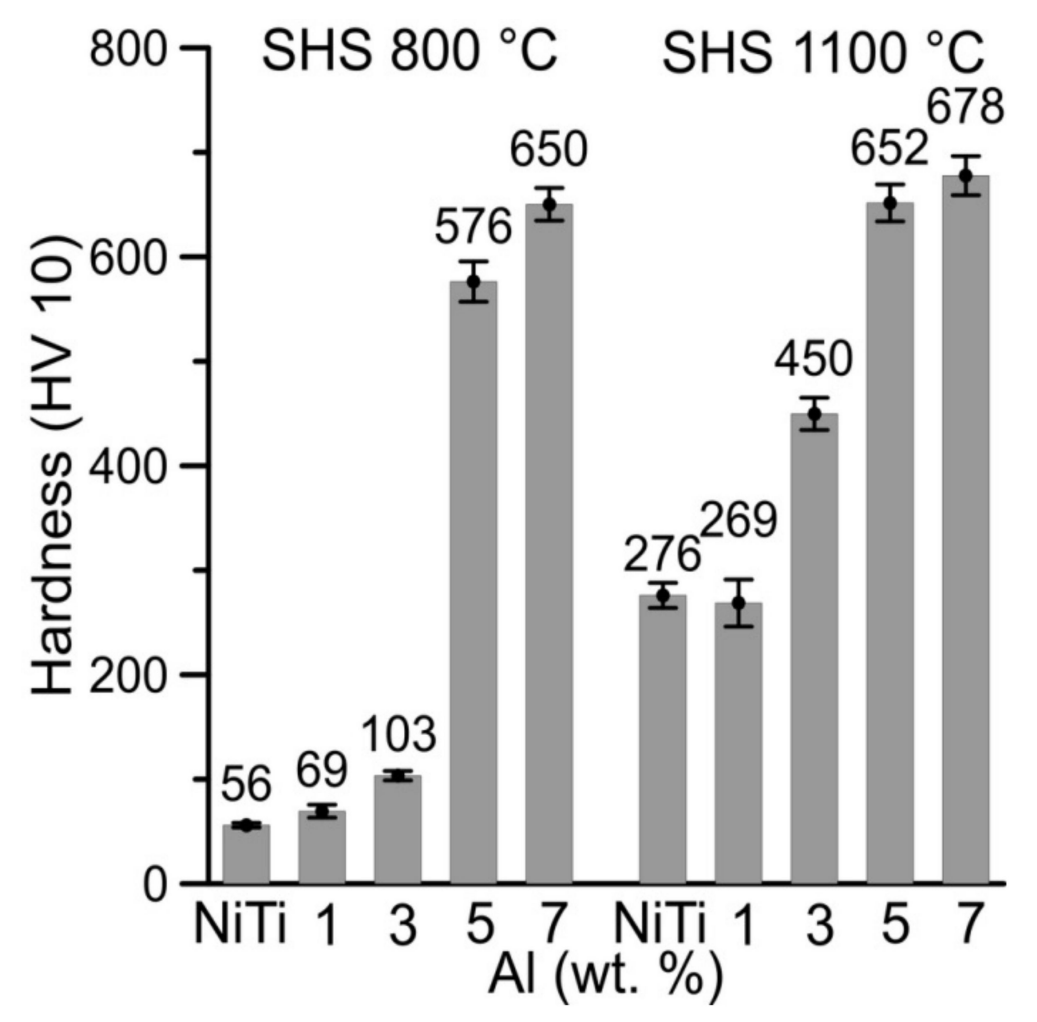

Figure 11. Hardness of samples sintered at 800 and $1100{ }^{\circ} \mathrm{C}$.

\section{Materials and Methods}

The metallic powders with the following particle sizes and purities were used as reagents: nickel $(<150 \mu \mathrm{m} ; 99.99 \mathrm{wt} \%)$, titanium $(<44 \mu \mathrm{m} ; 99.5 \mathrm{wt} \%)$ and aluminum $(<44 \mu \mathrm{m} ; 99.7 \mathrm{wt} \%)$. The powder mixtures were blended in desired proportions (shown in Table 2) and uniaxially compressed at room temperature to cylindrical green bodies of $12 \mathrm{~mm}$ in diameter at a pressure of $450 \mathrm{MPa}$ for five minutes using LabTest 5.250SP1-VM universal loading machine (Labortech, Opava, Czech republic). The differential thermal analysis (DTA) of the Ni-Ti-Al compressed powder mixtures was carried out using the SETSYS Evolution-1750 device (Setaram, Caluire, France) by the heating rate ranging from 50 to $1200{ }^{\circ} \mathrm{C}$ with the heating rate of $30^{\circ} \mathrm{C} \cdot \mathrm{min}^{-1}$ in argon atmosphere and alumina crucible. The weight of the tested samples was approximately $80 \mathrm{mg}$, which was mechanically separated from the compressed powder mixture. The substitution for the DTA with a maximal applicable heating rate of $30^{\circ} \mathrm{C} \cdot \mathrm{min}^{-1}$ was searched for measuring and observing of influence of heating rate on the initial temperature of TE-SHS reaction. The device composed of induction furnace with the protective argon atmosphere and optical pyrometer OPTRIS P20 2M (Optris, Portsmouth, NH, USA) can record the heating curve with the initial temperature at a heating rate of approximately $110^{\circ} \mathrm{C} \cdot \mathrm{min}^{-1}$.

Table 2. Chemical compositions of the prepared powder mixtures.

\begin{tabular}{cccc}
\hline \multirow{2}{*}{ Sample } & \multicolumn{3}{c}{ Chemical Composition (in wt \%) } \\
\cline { 2 - 4 } & $\mathbf{N i}$ & $\mathbf{T i}$ & $\mathbf{A l}$ \\
\hline NiTi46 & 54.0 & 46.0 & - \\
NiTiAl1 & 53.5 & 45.5 & 1.0 \\
NiTiAl3 & 52.4 & 44.6 & 3.0 \\
NiTiAl5 & 51.3 & 43.7 & 5.0 \\
NiTiAl7 & 50.2 & 42.8 & 7.0 \\
\hline
\end{tabular}


The TE-SHS reaction of the compressed powder mixtures was performed in the fused silica ampoules evacuated to $10^{-2} \mathrm{~Pa}$ and sealed. The ampoules with the samples was inserted to the electric resistance furnace preheated to the temperature of 800 and $1100{ }^{\circ} \mathrm{C}$ for a process duration $20 \mathrm{~min}$ followed by cooling in air. The NiTiAl5 sample was annealed at $610{ }^{\circ} \mathrm{C}$ for 20 min to determine which phase is formed as the first. The metallographic samples were ground by sandpapers P180-P4000 (Hermes Schleifmittel GmbH, Hamburg, Germany) with SiC abrasive elements, polished by diamond pastes and etched in Kroll's reagent $\left(10 \mathrm{~mL} \mathrm{HF}, 5 \mathrm{~mL} \mathrm{HNO}_{3}\right.$, and $85 \mathrm{~mL} \mathrm{H}_{2} \mathrm{O}$ ). The microstructure was observed by the scanning electron microscope TESCAN VEGA 3 LMU (Tescan, Brno, Czech republic) equipped with the OXFORD Instruments X-max $20 \mathrm{~mm}^{2}$ SDD EDS analyser (Oxford Instruments, High Wycombe, UK) for identification of the chemical composition of the individual phases. The phase composition of the alloys was identified on the samples' ground surfaces of using X-ray diffraction (XRD) by the means of PANalytical X'Pert Pro diffractometer (PANalytical, Almeo, The Netherlands) with a copper anode. The Vickers hardness test with a load of $10 \mathrm{~kg}$ at laboratory temperature was performed in order to compare the quality of sintering at temperatures of 800 and $1100{ }^{\circ} \mathrm{C}$.

\section{Conclusions}

This investigation describes the differences in the reactive sintering mechanism between the binary NiTi46 and the powder mixture with various additions of aluminum NiTiAl1-7 wt \%. The changes in sintering duration were observed when the addition of aluminum into NiTi powder mixture was higher than $5 \mathrm{wt} \%$. The diffusion-controlled reaction with the $\mathrm{Ti}_{2} \mathrm{Ni}$ phase as a product occurs below the $\alpha \rightarrow \beta$ Ti transformation temperature $\left(882{ }^{\circ} \mathrm{C}\right)$ and close to this temperature $\left(860-890{ }^{\circ} \mathrm{C}\right)$ TE-SHS is initiated in NiTi46, NiTiAl1, and NiTiAl3 wt \% powder mixtures. The aluminum content $5-7$ wt $\%$ in powder mixture activates the TE-SHS at approximately $630-640{ }^{\circ} \mathrm{C}$ by heating rate $110^{\circ} \mathrm{C} \cdot \mathrm{min}^{-1}$ and higher. The microstructures of the samples sintered at the temperatures of 800 and $1100{ }^{\circ} \mathrm{C}$ are very similar in the case of NiTiAl7 alloys.

Author Contributions: Pavel Salvetr coordinated the work, analyzed data and wrote the article. Andrea Školáková realized thermal analysis by recording of optical pyrometer. Cyprien Hudrisier prepared samples for metallographic observations and measured hardness. Pavel Novák contributed by DTA and XRD analysis evaluation and was responsible for final correction. Dalibor Vojtěch coordinated the activities in the context of the P108/12/G043 project.

Funding: Financial support from specific university research (MSMT no. 21-SVV/2018) and Czech Science Foundation, project no. P108/12/G043.

Conflicts of Interest: The authors declare no conflict of interest.

\section{References}

1. Novak, P.; Vojtech, D.; Serak, J.; Kubasek, J.; Prusa, F.; Knotek, V.; Michalcova, A.; Novak, M. Synthesis of intermediary phases in Ti-Al-Si system by reactive sintering. Chem. Listy 2009, 103, 1022-1026.

2. Elahinia, M.H.; Hashemi, M.; Tabesh, M.; Bhaduri, S.B. Manufacturing and processing of NiTi implants: A review. Prog. Mater. Sci. 2012, 57, 911-946. [CrossRef]

3. Sadrnezhad, S.K.; Raz, S.B. Interaction between refractory crucible materials and the melted NiTi shape-memory alloy. Metall. Mater. Trans. B 2005, 36, 395-403. [CrossRef]

4. Novák, P.; Mejzlíková, L.; Michalcová, A.; Čapek, J.; Beran, P.; Vojtěch, D. Effect of SHS conditions on microstructure of NiTi shape memory alloy. Intermetallics 2013, 42, 85-91. [CrossRef]

5. Krone, L.; Schüller, E.; Bram, M.; Hamed, O.; Buchkremer, H.P.; Stöver, D. Mechanical behaviour of NiTi parts prepared by powder metallurgical methods. Mater. Sci. Eng. A 2004, 378, 185-190. [CrossRef]

6. Knaislová, A.; Novák, P.; Cygan, S.; Jaworska, L.; Cabibbo, M. High-pressure spark plasma sintering (HP SPS): A promising and reliable method for preparing Ti-Al-Si alloys. Materials 2017, 10, 465. [CrossRef] [PubMed]

7. Novák, P.; Moravec, H.; Salvetr, P.; Prǔša, F.; Drahokoupil, J.; Kopeček, J.; Karlík, M.; Kubatík, T.F. Preparation of nitinol by non-conventional powder metallurgy techniques. Mater. Sci. Technol. 2015, 31, 1886-1893. [CrossRef] 
8. Yeh, C.L.; Sung, W.Y. Synthesis of niti intermetallics by self-propagating combustion. J. Alloys Compd. 2004, 376, 79-88. [CrossRef]

9. Biswas, A.; Roy, S.K. Comparison between the microstructural evolutions of two modes of SHS of NiAl: Key to a common reaction mechanism. Acta Mater. 2004, 52, 257-270. [CrossRef]

10. Whitney, M.; Corbin, S.F.; Gorbet, R.B. Investigation of the mechanisms of reactive sintering and combustion synthesis of NiTi using differential scanning calorimetry and microstructural analysis. Acta Mater. 2008, 56, 559-570. [CrossRef]

11. Cluff, D.; Corbin, S.F. The influence of Ni powder size, compact composition and sintering profile on the shape memory transformation and tensile behaviour of NiTi. Intermetallics 2010, 18, 1480-1490. [CrossRef]

12. Cluff, D.R.; Corbin, S.F.; Gharghouri, M.A. Investigating the influence of Ti powder purity on phase evolution during NiTi sintering using in-situ neutron diffraction. Intermetallics 2017, 83, 43-54. [CrossRef]

13. Whitney, M.; Corbin, S.F.; Gorbet, R.B. Investigation of the influence of Ni powder size on microstructural evolution and the thermal explosion combustion synthesis of NiTi. Intermetallics 2009, 17, 894-906. [CrossRef]

14. Jabur, A.S.; Al-Haidary, J.T.; Al-Hasani, E.S. Characterization of Ni-Ti shape memory alloys prepared by powder metallurgy. J. Alloys Compd. 2013, 578, 136-142. [CrossRef]

15. Sina, H.; Surreddi, K.B.; Iyengar, S. Phase evolution during the reactive sintering of ternary Al-Ni-Ti powder compacts. J. Alloys Compd. 2016, 661, 294-305. [CrossRef]

16. Novák, P.; Školáková, A.; Pignol, D.; Průša, F.; Salvetr, P.; Kubatík, T.F.; Perriere, L.; Karlík, M. Finding the energy source for self-propagating high-temperature synthesis production of NiTi shape memory alloy. Mater. Chem. Phys. 2016, 181, 295-300. [CrossRef]

(C) 2018 by the authors. Licensee MDPI, Basel, Switzerland. This article is an open access article distributed under the terms and conditions of the Creative Commons Attribution (CC BY) license (http:// creativecommons.org/licenses/by/4.0/). 